\title{
Expression of the Weaver Gene in Dopamine-Containing Neural Systems is Dose-Dependent and Affects Both Striatal and Nonstriatal Regions
}

\author{
Suzanne Roffler-Tarlov and Ann M. Graybiel \\ Departments of Neurology and Anatomy and Cell Biology, Tufts University School of Medicine, Boston, \\ Massachusetts 02111, and Whitaker College and Department of Psychology, Massachusetts Institute of \\ Technology, Cambridge, Massachusetts 02139
}

In an earlier report we presented evidence pointing to a differential effect of the mutant gene weaver on the dopamine-containing fiber systems innervating the striatum. In mice homozygous for the weaver mutation, there is a severe loss of dopamine in the caudoputamen, the main target of the nigrostriatal system. By contrast, dopamine is entirely conserved in the nucleus accumbens, a target of the mesolimbic system, and is moderately affected in the olfactory tubercle. The present study shows that these defects in dopamine are gene dose-dependent, that they are established by the end of the first month of life, and that the losses are permanent and not progressive. As in homozygous weavers, the greatest defects in striatal dopamine in heterozygous weavers occur in the dorsolateral caudoputamen and the lateral olfactory tubercle.

The abnormalities in the striatal dopamine content of weaver mice are not accompanied by abnormalities in the turnover of dopamine, judging from measurements of the dopamine metabolite dihydroxyphenylacetic acid. Norepinephrine content is also normal in each striatal region. No deficits in striatal dopamine occur in mice homozygous for the mutant genes staggerer and Purkinje cell degeneration, which, like the weaver mutation, result in ataxia and cerebellar pathology.

A survey of nonstriatal regions in the weaver mice showed that the effects of the weaver gene on the dopamine-containing innervation of the forebrain are not confined to striatal targets but also extend to the septum and the hypothalamus. By contrast, dopamine in the frontal cortex, the amygdala, the olfactory bulb, and the retina is entirely spared. The pattern and extent of loss of dopamine in the weaver forebrain is thus regionand system-specific. In confirmation of our initial findings, a ca. $30 \%$ depletion of dopamine occurs in the weaver midbrain, the region containing the cell bodies of origin of the mesostriatal dopamine systems. A comparison of histofluorescent sections through weaver and control midbrains revealed a reduction of catecholamine-containing neurons in the pars compacta of the weaver animals.

These results point to a subpopulation of dopamine-containing neurons as primary targets of the weaver gene or as being closely associated with such primary targets. As a gene-dose effect has also been shown for the cerebellar granule cell loss in the weaver, the mutant gene must have at least 2 cellular

\footnotetext{
Received Jan. 7, 1986; revised Apr. 30, 1986; accepted May 5, 1986.

This work was supportcd by National Institutes of Hcalth Grant NS20181 and by a grant from the American Parkinson Disease Association and the Seaver Institute. We wish to thank Mr. David Pugatch, Mr. Alfred Giuffreda, and Miss Dianne Sahagian for technical support and Mr. Henry Hall for photography.

Correspondence should be addressed to Suzanne Roffler-Tarlov, Departments of Neurology and Anatomy and Cell Biology, 136 Harrison Avenue, Boston, MA 02111 .

Copyright (C) 1986 Society for Neuroscience $0270-6474 / 86 / 113319-12 \$ 02.00 / 0$
}

targets. We suggest that the cerebellar and mesostriatal pathologies may be linked by a common molecular mechanism.

Two defects, one obvious and the other well hidden, are known to be present in the brains of mice that carry the autosomal recessive gene weaver. This mutation results in an atrophy of the cerebellum that is so severe in homozygous weavers that it can be detected after a glance at the intact brain. As was first reported by Sidman et al. in 1965, this macroscopic defect reflects an early postnatal loss of granule cells in the cerebellar cortex. A second abnormality in the weaver brain affects the forebrain and is concealed from view because it does not result in a marked atrophy or disruption of cellular architecture in the affected regions. This defect was first revealed biochemically as a selective reduction in the content of the neurotransmitter dopamine in brain (Lane et al., 1977), and was subsequently shown both by biochemical analysis and by fluorescence histochemistry to affect certain regions in the forebrain innervated by dopamine-containing fibers from the midbrain (Roffler-Tarlov and Graybiel, 1984; Schmidt et al., 1982).

In an earlier report, we presented evidence for a striking regional specificity in the effect of the weaver mutation on the content of dopamine in different parts of the striatum (RofflerTarlov and Graybiel, 1984). In the caudoputamen of homozygous mutants, there was an almost $70 \%$ reduction of dopamine relative to that in heterozygous controls, whereas in the nucleus accumbens, dopamine was entircly conserved. This anatomical pattern of dopamine loss strongly suggested that the weaver gene affects the dopamine-containing innervation of the forebrain according to recognized functional subdivisions (Ungerstedt, 1971).

We had 2 goals in the study reported here. First, we sought to determine whether the dopamine-containing nigrostriatal system affected in the weaver mice is likely to be a primary target of the weaver gene, as is true for the granule cells of the cerebellum. The cerebellar defect characteristic of homozygous weavers is manifested morphologically and biochemically in a less severe form in the heterozygous mice (Hatten et al., 1984a; Rakic and Sidman, 1973b, c; Rezai and Yoon, 1972; RofflerTarlov and Turey, 1982; Willinger and Margolis, 1985a, b). Thus, in the cerebellum, the presence of a single weaver allele results in a partial defect. To determine whether a heterozygote effect also occurs for the dopamine-containing innervation of the striatum, we measured the dopamine content of the caudoputamen, the nucleus accumbens, and the olfactory tubercle in each of the 3 genetic types, wv $/ w v,+/ w v$, and $+/+$. We also examined the dopamine content of these striatal districts in 2 other mutant mouse types exhibiting movement disorders as a result of autosomal recessive mutations expressed in the cerebellum. One of these, the staggerer mutant (sg), has in common with weaver a granule cell-deficient cerebellum (Sidman et al., 1962). The other, Purkinje cell degeneration (pcd), has in common an ataxia, but loses the Purkinje cells of the cerebellum 
(Mullen et al., 1976). By comparing these mutants to weavers, we tested for the possibilities that the dopamine defect in the weaver striatum might be attributable to abnormalities in motor behavior or cerebellar morphology, rather than being the result of a direct action of the weaver gene on dopamine-containing neurons or on cells affecting them.

Our second objective was to determine the range of action of the weaver gene on the dopamine-containing systems of the brain. We analyzed the content of dopamine present (1) in nonstriatal as well as in striatal regions of the forebrain normally innervated by dopamine-containing neurons of the midbrain, and (2) in regions that have intrinsic dopamine-containing neurons distinct from the dopaminergic cell groups of the midbrain. Simultaneously, we measured the concentrations of dihydroxyphenylacetic acid (DOPAC) and norepinephrine to identify the nature and specificity of any abnormality in dopamine content found. To establish unequivocally whether the defect in striatal dopamine was accompanied by a loss of dopamine in the midbrain, we mcasured the dopaminc content in samples of the midbrain containing neurons of cell groups A8, A9, and A10 of Dahlstrom and Fuxe (1964). The observations described below have been summarized, in part, in abstract form (RofflerTarlov and Graybiel, 1985b).

\section{Materials and Methods}

\section{Mutant and control mice}

Weaver, gene symbol wv

Homozygous weaver (wv/wv), heterozygous weaver $(+/ \mathrm{wv})$, and homozygous normal $(+/+)$ animals were on a C57BL/6JLe-A ${ }^{\text {wJ }} \times \mathrm{CBA} /$ $\mathrm{CaGnLeF}_{1}$ hybrid background. Mutant animals and most controls were obtained by breeding heterozygote pairs in a colony established with animals purchased from the Jackson Laboratory, Bar Harbor, Maine. Some $+1+$ animals were obtained from litters born of known $+1+$ C57BL6/CBA pairs. Mature wv/wv animals were identified behaviorally (Sidman, 1968; Sidman et al., 1965). The genetic type of the $+/ w v$ and $+/+$ animals was established postmortem by the macroscopic appearance and wet weight of the cerebellum. Compared to the cerebellum of the $+/+$ mouse, that of the $+/$ wv appears misshapen and slightly deflated, particularly at the midline (Rakic and Sidman, 1973a, b; Rezai and Yoon, 1972) and is reduced in weight (Roffler-Tarlov and Turey, 1982).

\section{Purkinje cell degeneration (pcd)}

The Purkinje cell degeneration mutation, an autosomal recessive, was maintained on a C57BL6 background. Mutants and controls were obtained by breeding heterozygote pairs purchased from the Jackson Laboratory. The $\mathrm{pcd} / \mathrm{pcd}$ animals were identified by their moderately ataxic gait, which appears on about postnatal day 25 . The heterozygous pcd and homozygous normal animals were indistinguishable behaviorally and morphologically. As controls, we chose littermates with apparently normal motor behavior, which could have been $+/+$ or $+/$ pcd.

\section{Staggerer (sg)}

The sg/sg mutants and controls were on C57BL6 stock and were kindly donated by Dr. Karl Herrup of Yale University. This autosomal recessive mutation results in a lack of granule cells (Sidman et al., 1962), reduced numbers of Purkinje cells (Herrup and Mullen, 1979), and malformation of the residual Purkinje cells (I andis and Sidman, 1978; Sotelo, 1975). The sg/sg animals were identified behaviorally by their marked ataxia. Controls were $+/+$ at the $s g$ locus and were recognized as such by a genetic coat-color marker.

\section{Biochemical measurements}

\section{Tissue dissection}

All animals were anesthetized with Nembutal $(40 \mathrm{mg} / \mathrm{kg})$ and were perfused through the heart with $0.1 \mathrm{M}$ PBS maintained at $4^{\circ} \mathrm{C}$. The eyes were enucleated; the retinas were removed, and any adhering vitreous humor or pigment epithelium was removed. The olfactory bulbs were removed from the intact brain. All other assays were performed on tissue samples obtained by freehand dissection from ca. 20 coronal $420-\mu \mathrm{m}$-thick slices of cold-hardened and agar-encased brains cut with a tissue sectioner (Zigmond and Ben-Ari, 1976). The tissue slices were kept cold throughout the dissection by placing them on a cooling stage mounted on a stereomicroscope. The face of each transverse slice was viewed with intense scattered illumination from bclow so that individual tissue components could be recognized by their differential translucency (see Fig. 1). Standard dissection protocols for the slices were established in preliminary experiments. As nearly as possible, the entire region to be examined was removed from all slices in which it appeared. Samples from the right and left sides of the brain were pooled after preliminary experiments established that there were no left/right differences in catecholamine content. The dissections were carried out as follows.

Frontal cortex. Samples were taken from slices 1-4 (Fig. 1) and included all of the frontal pole and medial and lateral frontal cortex as far caudal as the anterior extreme of the striatum. Great care was taken not to involve any striatal tissue in these samples, which therefore did not include the caudal limits of medial frontal cortex abutting the rostral pole of the caudoputamen.

Olfactory tubercle. Tissuc of the olfactory tubercle was dissected from slices 4-6 (Fig. 1) by following the gray matter from the rhinal sulcus medially to near the midline.

Nucleus accumbens. Samples were taken from slices 4-6 (Fig. 1), in which the limits of the nucleus were determined by the band of olfactory radiation fibers ventrally, the striated appearance of the caudoputamen dorsolaterally, and the change in translucency at the accumbens-septal border medially.

Caudoputamen. Samples were taken from slices 5-12 (Fig. 1) and were identified by the densely striated appearance of all but the dorsomedial corner of the caudoputamen. The globus pallidus could be identified by its darker appearance and was not included.

Septum. Samples were taken from slices 6-8 (Fig. 1) and included tissue dorsal to a line running between the ventral tips of the lateral ventricles.

Amygdala. Samples of amygdaloid tissue were dissected from slices 11 and 12 (Fig. 1) and mainly included the dopamine-rich central nucleus, identified as a rounded translucent zone at the foot of the caudoputamen.

Hypothalamus-preoptic area. Paramedian samples were taken from slices 8-13 (Fig. 1). The dorsal limit of each sample was at a level immediately above the dorsal tip of the third ventricle. The lateral limits were along vertical lines lateral to the fornix bundles. An attempt was made not to include the zona incerta in the samples.

Midbrain. Samples were taken from 5 caudal sections at levels corresponding to slices 14-18 of Figure 1 . In the most rostral section, the mammillary bodies were detached, but otherwise the brain stem was included in its entirety at each level. The aim was to include as much as possible of cell groups A8, A9, and A10 of Dahlstrom and Fuxe (1964).

\section{Extraction and measurement of dopamine, norepinephrine, and DOPAC}

The tissue samples were homogenized in $0.1 \mathrm{M} \mathrm{HClO} \mathrm{H}_{4}$ containing $1 \mathrm{~mm}$ sodium metabisulfite and were centrifuged at $15,000 \times \mathrm{g}$ for $15 \mathrm{~min}$. The pellet was assayed for its protein content by the method of Lowry et al. (1951). The supernatant was stored at $-70^{\circ} \mathrm{C}$ until assays were begun. The catecholamines in the supernatants were isolated on alumina minicolumns and eluted with $0.2 \mathrm{~N}$ or $0.4 \mathrm{~N} \mathrm{HClO}_{4}$. The catecholamines were then separated by high-performance liquid chromatography using a reversed-phase column and were subsequently quantified by electrochemical detection (Moyer and Jiang, 1978). Recovery of the catecholamines was estimated by the addition of a synthetic catechol substance, 3,4-dihydroxybenzylamine, as an internal standard to each sample before homogenization and by measuring standard solutions of dopamine, norepinephrine, and DOPAC isolated on separate alumina columns. The recovery of the synthetic catechol averaged $65 \%$ and was representative of recoveries of both dopamine and norepinephrine but not of DOPAC, which had average recovery of $45 \%$. Statistical analysis was carried out on group means of sample values using a 2-tailed Student's $t$ test when comparison of 2 means was involved (e.g., $+/ \mathrm{wv}$ vs $\mathrm{wv} / \mathrm{wv}$ ). When multiple comparisons were made among $+/+,+/ \mathrm{wv}$, $+/ w v$, and wv/wv animals, statistical assessment was made by a 1-way analysis of variance followed by the Newman-Keuls test (Winer, 1971). 
Table 1. Content of dopamine and protein in 3 striatal regions and in the midbrain of homozygous normal $(+/+)$, heterozygous weaver $(+/$ wv) and homozygous weaver (wv/wv) mice

\begin{tabular}{|c|c|c|c|c|c|c|}
\hline \multirow[b]{2}{*}{ Region } & \multicolumn{3}{|c|}{ Dopamine (pmol/mg protein) } & \multicolumn{3}{|l|}{ Protein (mg) } \\
\hline & $+/+$ & $+/ \mathrm{wv}$ & $w v / w v$ & $+1+$ & $+/ w y$ & $\mathrm{wv} / \mathrm{wv}$ \\
\hline Caudoputamen & $408 \pm 17$ & $\begin{array}{c}356 \pm 16^{a} \\
(87 \%)\end{array}$ & $\begin{array}{l}118 \pm 6^{a b} \\
(29 \%)\end{array}$ & $1.28 \pm 0.02$ & $\begin{array}{l}1.36 \pm 0.04 \\
(106 \%)\end{array}$ & $\begin{array}{l}1.10 \pm 0.02^{a b} \\
(86 \%)\end{array}$ \\
\hline Olfactory tubercle & $393 \pm 23$ & $\begin{array}{l}303 \pm 15^{a} \\
(77 \%)\end{array}$ & $\begin{array}{l}205 \pm 16^{a b} \\
(52 \%)\end{array}$ & $0.187 \pm 0.006$ & $\begin{array}{l}0.179 \pm 0.008 \\
(96 \%)\end{array}$ & $\begin{array}{l}0.190 \pm 0.001 \\
(102 \%)\end{array}$ \\
\hline N. accumbens & $301 \pm 30$ & $\begin{array}{l}357 \pm 22 \\
(119 \%)\end{array}$ & $\begin{array}{l}325 \pm 22 \\
(108 \%)\end{array}$ & $0.145 \pm 0.011$ & $\begin{array}{l}0.166 \pm 0.012 \\
(114 \%)\end{array}$ & $\begin{array}{l}0.153 \pm 0.014 \\
(106 \%)\end{array}$ \\
\hline Midbrain & $7.0 \pm 0.7$ & $\begin{array}{l}7.0 \pm 0.3 \\
(100 \%)\end{array}$ & $\begin{array}{l}4.8 \pm 0.3^{a b} \\
(69 \%)\end{array}$ & $4.96 \pm 0.17$ & $\begin{array}{l}4.90 \pm 0.27 \\
(99 \%)\end{array}$ & $\begin{array}{l}4.47 \pm 0.31 \\
(90 \%)\end{array}$ \\
\hline
\end{tabular}

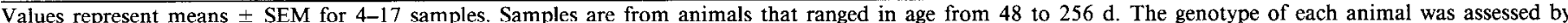

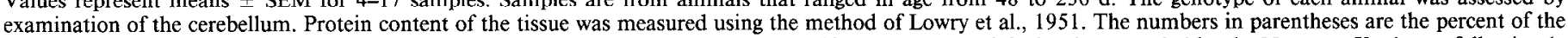

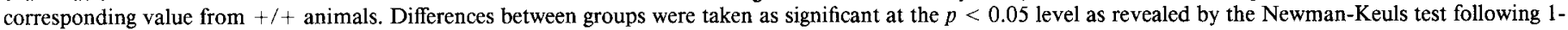
way analysis of variance.

a Difference between indicated group and $+/+$ is significant.

${ }^{b}$ Value for $w v / w v$ is significantly different from $+/+$ and from $+/ w v$.

\section{Catecholamine histofluorescence}

The brains of $5 \mathrm{wv} / \mathrm{wv}, 5+/ \mathrm{wv}$, and $4+/+$ mice were prepared for catecholamine histofluorescence according to the method of de la Torre (1980). Brains were removed from mice deeply anesthetized with Nembutal, were rapidly frozen in pulverized dry ice, and were cut in a cryostat maintained at $-12^{\circ} \mathrm{C}$. Sections were thaw-mounted, briefly exposed to glyoxylic acid, dried, coverslipped, and studied under incident fluorescence illumination with the aid of a Leitz Ploemopak fitted with filter module D.

\section{Results}

\section{Mesostriatal dopamine systems in the weaver brain: Dopamine concentrations in the striatum and midbrain}

Figure 2 shows the concentrations of dopamine measured in 3 striatal regions and in the midbrain of homozygous weaver mutants ranging in age from $35 \mathrm{~d}$ to 18 months. The results are expressed as percentages of values measured in heterozygous littermate controls and are plotted separately for groups of animals taken for study at progressively increasing ages.

In confirmation of our original findings, there was a marked deficit in dopamine in the weaver caudoputamen and a moderate defect in the olfactory tubercle of the weaver mice but no detectable dopamine deficiency in the nucleus accumbens of these mutants (Fig. $2 A$ ). This pattern of loss was already evident in the youngest mice studied and was maintained at almost exactly the same levels in the older animals. In the 35-d-old weavers, the caudoputamen contained $34 \%$ of the control levels of dopamine, the olfactory tubercle $73 \%$, and the nucleus accumbens $103 \%$.

At each age, an abnormally low concentration of dopamine was present also in the midbrain of the weaver animals (approximately $70 \%$ of control levels; see Fig. $2 B$ ). As in the striatum, the defect was present at its full value in 35-d-old animals and did not change in the older animals.

Comparison of dopamine content in the striatum of homozygous normal $(+/+)$, heterozygous weaver $(+/ w v)$, and homozygous weaver ( $w v / w v)$ mice

Table 1 summarizes measurements of the content of dopamine in the caudoputamen, olfactory tubercle, and nucleus accumbens from known homozygous normal $(+/+)$ mice, known heterozygous animals $(+/ \mathrm{wv})$, and homozygous weavers. Total protein values (Lowry et al., 1951) for each striatal region are also shown. When possible, comparisons were made among littermates of the 3 genetic types; some measurements were carried out on age-matched $+/+$ mice culled from a colony of $+/+$ animals maintained on the same (C57BL6/CBA) background. The data from mice of different ages (48-256 d) were pooled, as no age-related differences in the striatal dopamine in weaver mice had been found in our initial study of wv/wv and $+/$ wv controls (Fig. 2).

Clear evidence for a heterozygote effect was evident in the 2 striatal regions vulnerable to a dopamine deficiency in the homozygous weaver mice (Table 1). Relative to the homozygous normal mice, the heterozygotes showed a reduction in dopamine of $13 \%$ in the caudoputamen and $23 \%$ in the olfactory tubercle. Dopamine loss in the homozygous weaver mutants is accordingly even more severe than originally judged from comparisons with heterozygous controls: In the caudoputamen there was a $71 \%$ reduction of dopamine measured against $+/+$ values (as opposed to $67 \%$ ); and in the olfactory tubercle there was a $48 \%$ loss of dopamine (as opposed to $32 \%$ ). Values for dopamine in the nucleus accumbens were roughly equivalent in the 3 genetic types. The midbrain of the weaver animals showed a $31 \%$ reduction in dopamine content relative to $t /+$ control valves. There was no significant difference in the dopamine content of midbrain from $+/ w v$ and $w v / w v$ animals.

Protein content in the wv/wv animals was different from that in the $+/+$ and the $+/$ wv animals in the caudoputamen but in no other region examined. A reduction in protein of $14 \%$ occurred between wv/wv and $+1+$ animals. No reduction of protein content was found in the caudoputamen of the heterozygotes relative to $+/+$ mice. Thus, a heterozygote effect was not present for total protein in the striatum but was apparent for dopamine levels both in the caudoputamen and, most prominently, in the olfactory tubercle.

Histofluorescence in the striatum and midbrain of homozygous normal $(+/+)$, heterozygous weaver $(+/ w v)$, and homozygous weaver $(w v / w v)$ mice

Representative cross sections through the striatum of the 3 genetic types are shown in Figure 3. The sections show approximately matched levels through the caudoputamen, nucleus accumbens, and olfactory tubercle. The striking loss of dopamine histofluorescence reported for the caudoputamen of the weaver animals relative to heterozygous controls was readily confirmed as was the apparent diminution of catecholamine histofluorescence in the lateral part of the olfactory tubercle. As shown in Figure $3 C$, the diminution of fluorescence in the caudoputamen 


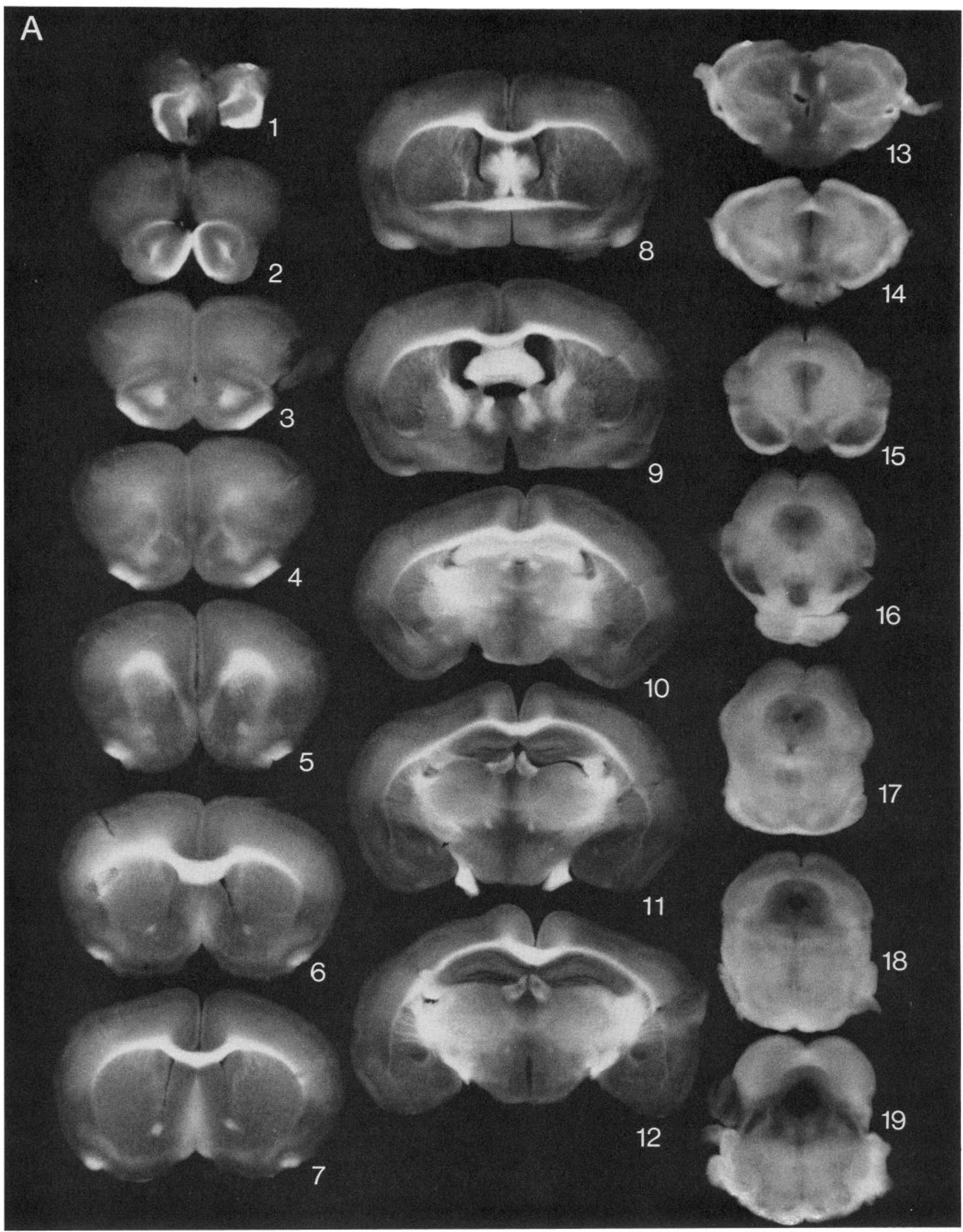


B
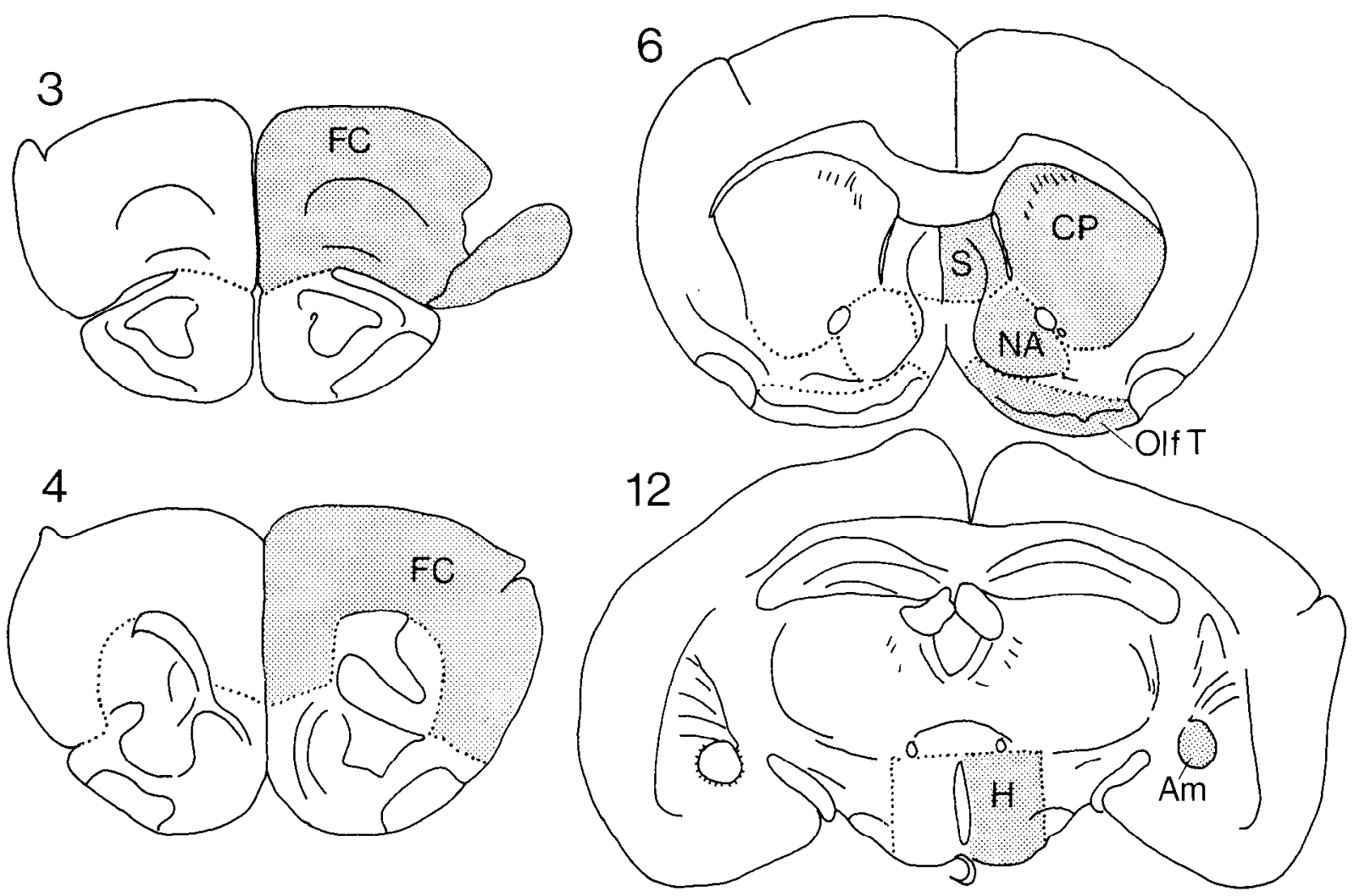

Figure 1. A, Photograph illustrating typical series of unstained transverse $420-\mu \mathrm{m}$-thick slices prepared for dissection. Standard series contained 19-20 slices. See Materials and Methods for levels from which different brain regions were dissected. $B$, Drawings corresponding to series 3, 4, 6 , and 12 of $A$ illustrating borders of regions selected for dissection. $F C$, prefrontal cortex; $C P$, caudoputamen; $S$, septum; $N A$, nucleus accumbens; Olf $T$, olfactory tubercle; $H$, hypothalamus; $A m$, amygdala.

affected especially its dorsolateral part. No quantitative assessment of the fluorescence was carried out, but patterns of histofluorescence visible were consistent with a partial loss of dopamine in the olfactory tubercle of the weaver heterozygote relative to the homozygote's content and also were compatible with the biochemical finding of a partial loss of dopamine in the weaver heterozygotes. Neither in the heterozygote nor in the homozygous weaver did the levels of histofluorescence visible in the nucleus accumbens appear to differ from those of the homozygous controls. Thus, the anatomical patterns were in accord with those indicated by the biochemical assays of dopamine in these 3 striatal districts.

In the midbrain (Fig. 4), fluorescent neurons were abundant in the ventral tegmental area (cell group A10) and in the retrorubral area (cell group A8), and such neurons were also present in the pars compacta of the substantia nigra (cell group A9). No attempt was made to map in detail the locations of surviving midbrain neurons using the histofluorescent material, as this is being done as part of a study of the distribution of tyrosine hydroxylase immunoreactive neurons in the weaver mouse (A. M. Graybiel and S. Roffler-Tarlov, unpublished observations). It is important to note, however, that in the weaver mice, fluorescent cell bodies were found in positions corresponding to each of the 3 midbrain cell groups defined by Dahlstrom and Fuxe, including cell group A9, the source of the main dopamine-containing innervation of the caudoputamen. Photomicrographs of fluorescent neurons in the A9 cell group (substantia nigra, pars compacta) are shown in Figure 4 for wv/wv and $+/+$ mice. At the level shown, the weaver's substantia nigra seems to contain fewer fluorescent neurons in the ventral part of the pars compacta than does the pars compacta of the homozygous normal mouse. Such a distribution would fit with the anatomical pattern of deficient fluorescence in the weaver's caudoputamen, as the ventral pars compacta is known to project to the dorsal caudoputamen (Fallon and Moore, 1978; Nauta et al., 1978). Detailed serial scction analysis is ncccssary, howcver, for adcquatc topographic comparisons, and the histofluorescence material was not suitable for such a study.

\section{Content of dopamine and a metabolite, DOPAC, in the 3 striatal targets of mesotelencephalic fiber systems}

The concentrations of dopamine and DOPAC extracted from the caudoputamen, the olfactory tubercle, and the nucleus accumbens were compared for $+/+,+/ \mathrm{wv}$, and $w v / w v$ littermates (Table 2). Neither catecholamine was changed in concentration in the nucleus accumbens of $+/ w v$ or $w v / w v$ animals relative to $+/+$ controls. In the caudoputamen and the olfactory tubercle, the decrease in content of DOPAC was proportional to that of dopamine. The mean ratio DOPAC/dopamine was not significantly different for the $+/+,+/ w v$, and $w v / w v$ groups in any of the regions sampled, indicating that the rate of formation and use of residual dopamine is unchanged in the affected striatal regions of the weaver brain.

\section{Dopamine in nonstriatal targets of mesotelencephalic fiber systems}

Table 3 summarizes measurements of the content of dopamine in 3 nonstriatal regions of the forebrain: the frontal cortex, a major target of the mesocortical dopamine system; and 2 nonstriatal regions classified as targets of the mesolimbic system, the septum and the amygdaloid complex. Each region was examined in weaver mutants, heterozygous weaver littermates, 
Figure 2. A, Dopamine concentrations in 3 striatal regions of weaver mice are expressed as a percentage of values obtained from control heterozygous littermates. Each point is the average of 3-9 animals \pm SEM. Where there are no error bars, the point represents the comparison of a single weaver animal with its littermate control. Weavers and littermate control animals were examined at ages ranging from $35 \mathrm{~d}$ to 18 months. $B$, The concentration of dopamine in the midbrain of weaver mice ranging in age from $35 \mathrm{~d}$ to 18 months is expressed as a percentage of values from heterozygous controls.

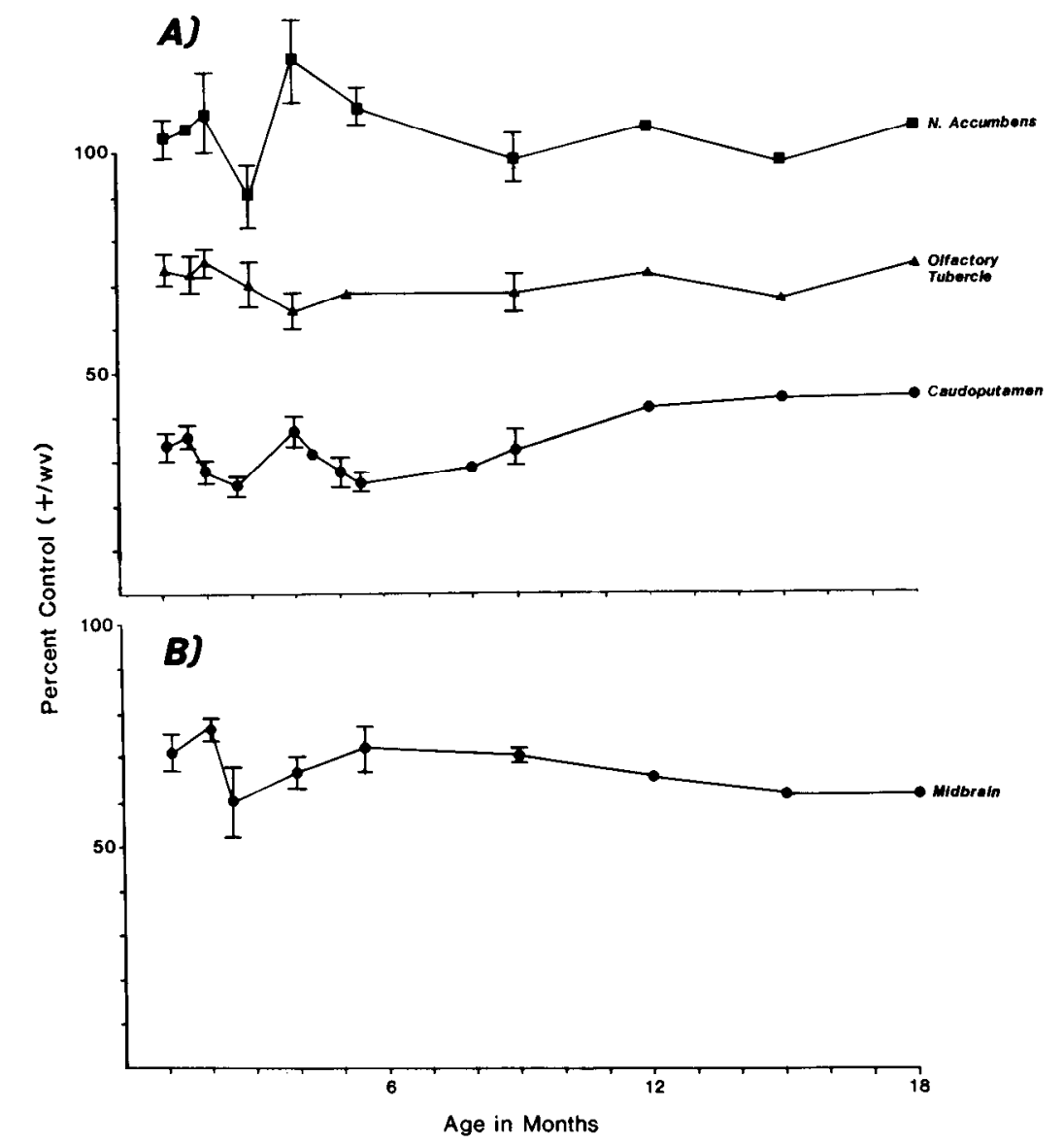

putamen, $4 \%$ in the olfactory tubercle, and $10 \%$ in the nucleus accumbens. As shown in Table 5, the concentrations of norepinephrine in each of these striatal districts and in the septum and midbrain were measured in homozygous normal animals, as well as in heterozygous control and homozygous weaver mutants as part of the study of possible heterozygote effects. No differences were found among the groups.

\section{Dopamine concentrations in the striatum of Purkinje cell degeneration and staggerer mutants}

In sharp contrast to the findings in the weaver mice, no deficit in the content of dopamine was present in the striatum of the 2 other types of neurological mutant mice studied (Table 6). The values for concentrations of dopamine in the caudoputamen, olfactory tubercle, and nucleus accumbens in their controls were similar to those found in the weaver controls (compare Tables 1 and 6).

\section{Discussion}

Primary and secondary targets of the weaver mutant gene

The actions of mutant genes in the nervous system are both direct and indirect. The cellular target of the direct action of a mutant gene is obliged to suffer its fate regardless of its environment because the genetic defect is intrinsic to the cell itself. By contrast, a cell that is affected as a secondary consequence of the action of a gene can be rescued in altered surroundings. Primary and secondary effects of mutant genes have been identified in several of the neurological mouse mutants. One clear example for the cerebellum occurs in the mutant mouse known as Lurcher, in which virtually all of the cerebellar Purkinje cells degenerate. In the brain stem of this mutant, the numbers of inferior olivary neurons (which have Purkinje cells as their tar- low. Expressed as a percentage of the dopamine concentrations, the concentrations of norepinephrine were $2 \%$ in the caudo-

\section{Concentrations of norepinephrine}

The content of norepinephrine was measured in all regions which dopamine levels were measured, excepting only the retina (Table 5). In no region was an abnormality found in the weaver mice. Compared to the high concentrations of dopamine present in the striatum (see Table 2), striatal norepinephrine levels were 

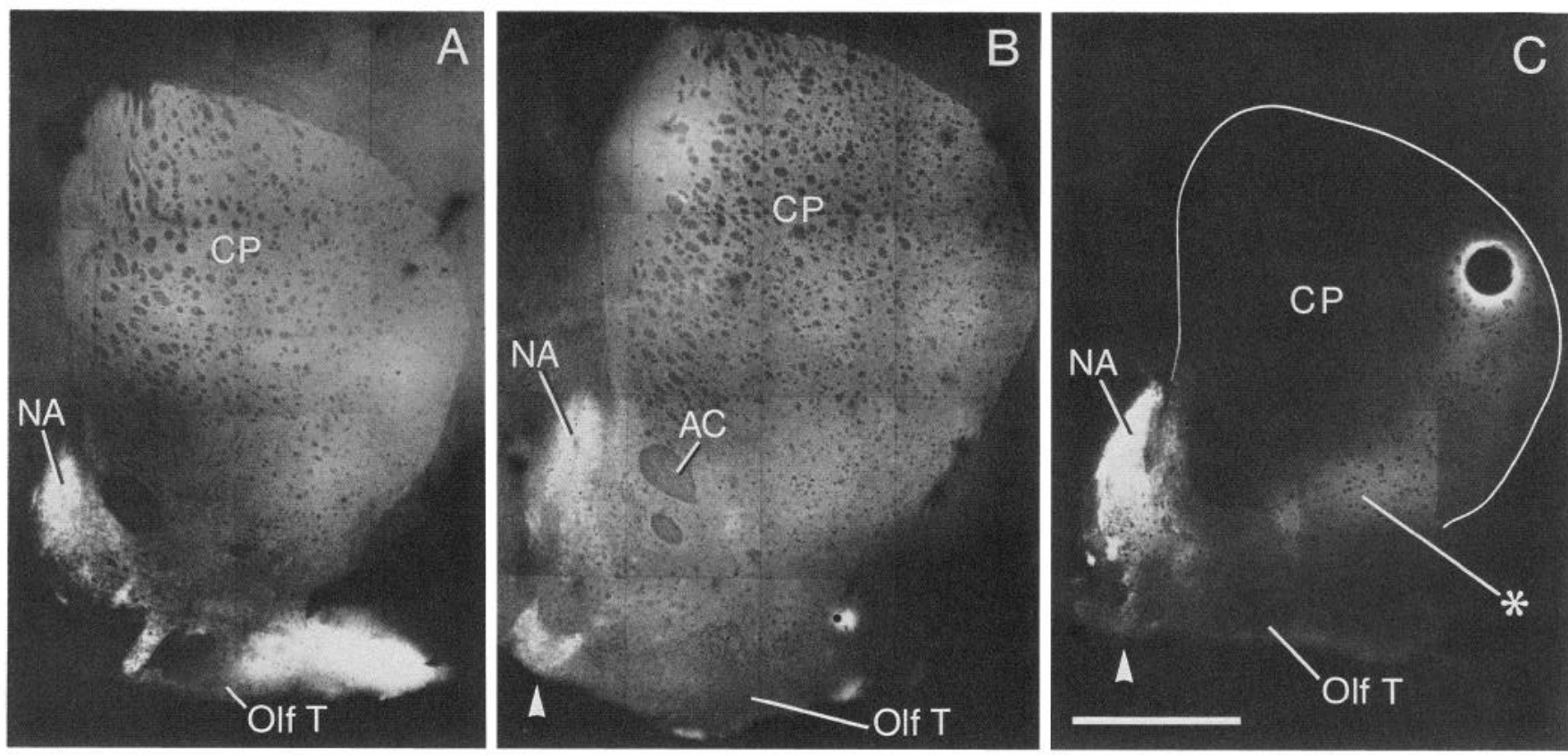

Figure 3. Striatal catecholamine-containing innervation demonstrated in cross sections through the striatal complex of $(A)$ homozygous normal $(+/+)$ control, $(B)$ heterozygous weaver $(+/ \mathrm{wv})$, and $(C)$ homozygous weaver (wv/wv) mice. Sections prepared by glyoxylic acid method. The $+/+$ and wv/wv mice were littermates. The heterozygote $(B)$ was an age-matched mouse from another litter. In $C$, small dark circle surrounded by corona is artifact produced at cutting. White line has been drawn to delineate caudoputamen medially, dorsally, and laterally. Homozygous normal mouse $(A)$ demonstrates densest fluorescence in nucleus accumbens $(N A)$ and olfactory tubercle $(O l f T)$ and strong but less dense fluorescence in caudoputamen $(C P)$. Heterozygote $(B)$ shows maintained dense fluorescence in nucleus accumbens and the medial part of the olfactory tubercle (arrowhead). Fluorescence in dorsolateral caudoputamen of the heterozygote may be somewhat weaker than that of the homozygous normal, but the difference is not marked. Loss of fluorescence in lateral olfactory tubercle is pronounced. Homozygous weaver striatum $(C)$ shows retention of dense fluorescence in nucleus accumbens, some fluorescence in medial part of olfactory tubercle (arrowhead), and ventrolateral caudoputamen (asterisk). Most of caudoputamen exhibits little fluorescence, the weakest fluorescence being dorsal. $A C$, anterior commissure. Scale bar, $1 \mathrm{~mm}$.

gets) are also severely reduced (Caddy and Biscoe, 1979). When the Lurcher's Purkinje cells are mixed with normal Purkinje cells in the cerebellum of a Lurcher $\leftrightarrow$ wild type chimera formed by embryo aggregation techniques, only Purkinje cells carrying the Lurcher phenotype die during subsequent development; the wild-type Purkinje cells are left intact (Wetts and Herrup, 1982). By contrast, inferior olivary neurons carrying the Lurcher phenotype survive in the chimeric inferior olivary complex, which

Table 2. Content of dopamine (DA) and 3,4-dihydroxyphenylacetic acid (DOPAC) in striatal targets of mesotelencephalic fiber systems (pmol/mg protein)

\begin{tabular}{|c|c|c|c|}
\hline Structure & DA & DOPAC & DOPAC/DA \\
\hline \multicolumn{4}{|c|}{ Caudoputamen } \\
\hline$+/+$ & $419 \pm 19$ & $50 \pm 3$ & $0.12 \pm 0.006$ \\
\hline$+/ w v$ & $348 \pm 14$ & $49 \pm 3$ & $0.14 \pm 0.008$ \\
\hline wv/wv & $128 \pm 6$ & $20 \pm 3$ & $0.16 \pm 0.024$ \\
\hline \multicolumn{4}{|c|}{ Nucleus accumbens } \\
\hline$+/+$ & $334 \pm 24$ & $41 \pm 6$ & $0.12 \pm 0.009$ \\
\hline$+/ w v$ & $378 \pm 27$ & $52 \pm 2$ & $0.14 \pm 0.007$ \\
\hline wv/wv & $322 \pm 20$ & $45 \pm 4$ & $0.14 \pm 0.003$ \\
\hline \multicolumn{4}{|c|}{ Olfactory tubercle } \\
\hline$+/+$ & $392 \pm 30$ & $39 \pm 7$ & $0.10 \pm 0.04$ \\
\hline$+/ \mathrm{wv}$ & $343 \pm 33$ & $35 \pm 6$ & $0.10 \pm 0.04$ \\
\hline wv/wv & $156 \pm 20$ & $21 \pm 3$ & $0.11 \pm 0.02$ \\
\hline
\end{tabular}

Values represent means \pm SEM for 4-9 samples of caudoputamen and nucleus accumbens from animals that ranged in age from 48 to $92 \mathrm{~d}$. The values for olfactory tubercle are from 3-4 samples from animals that were $35 \mathrm{~d}$ old. maintains a mosaic of neurons with normal and mutant genotypes (Wetts and Herrup, 1982). The most likely explanation for the rescue of the Lurcher olivary neurons in the chimeric animals is the presence of neuronal targets in the chimeric cerebellum, i.e., the Purkinje cells contributed by the normal component of the chimera. In the Lurcher mutant, the death of olivary neurons is thus probably a secondary epigenetic event, reflecting a loss of such targets, whereas the death of the Purkinje cells is a primary event attributable to the Lurcher gene.

A critical question about the weaver gene has been the identity of the primary cellular target in the cerebellum, where most

Table 3. Content of dopamine in nonstriatal targets of mesotelencephalic fiber systems: frontal cortex, amygdala, and septum

\begin{tabular}{llll} 
& \multicolumn{3}{l}{ Dopamine $(\mathrm{pmol} / \mathrm{mg}$ protein) } \\
\cline { 2 - 4 } Region & $+/+$ & $+/ \mathrm{wv}$ & $\mathrm{wv} / \mathrm{wv}$ \\
\hline Frontal cortex & - & $2.2 \pm 0.2$ & $2.3 \pm 0.3$ \\
\multirow{2}{*}{ Amygdala } & - & $158 \pm 14$ & $(105 \%)$ \\
& & & $(197 \pm 26$ \\
Septum & $43 \pm 5$ & $40 \pm 7$ & $27 \pm 1^{a}$ \\
& & & $(63 \%)$
\end{tabular}

Values are means \pm SEM of 4-10 samples. Weaver animals were compared with littermate controls; +/wv littermates for frontal cortex and amygdala and both $+/+$ and $+/ w v$ for septum. Frontal cortex was examined in animals between 60 and $270 \mathrm{~d}$ of age; septum and amygdala were examined in animals that were 73 $195 \mathrm{~d}$ old. Numbers in parentheses are the percentage of heterozygous or, in the case of the septum, the homozygous normal control values.

${ }^{a} p<0.002$. 

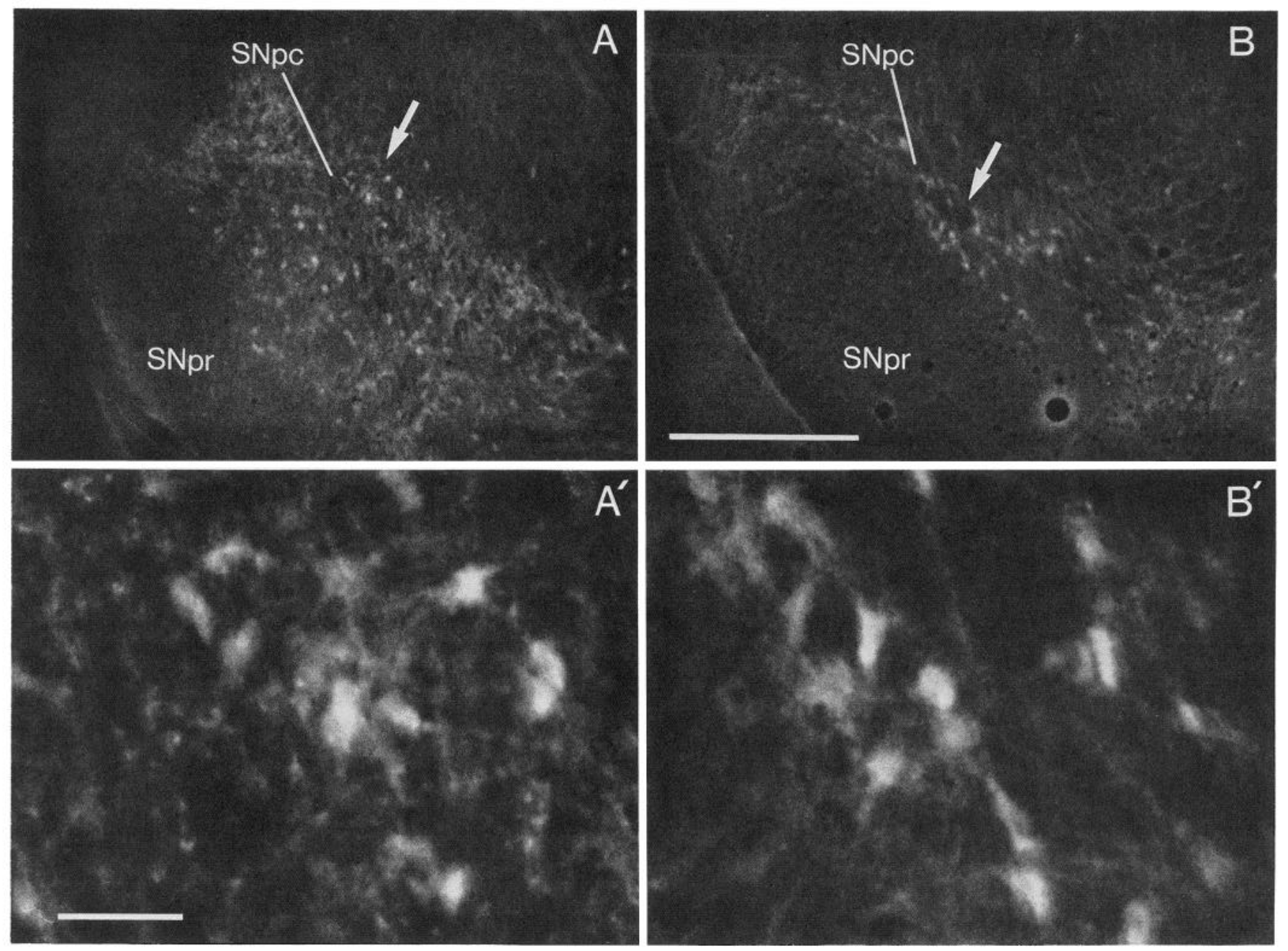

Figure 4. Catecholamine-containing neurons in cross sections through the nigral complex of homozygous normal $\left(A, A^{\prime}\right)$ and homozygous weaver $\left(B, B^{\prime}\right)$ mice. Sections through the striata of the same mice are shown in Figure 4. Arrows in $A$ and $B$ point to zones shown at higher magnification in $A^{\prime}$ and $B^{\prime}$, respectively. At the levels shown, there is a paucity of fluorescent neurons in the ventral pars compacta of the weaver relative to the control. $S N p c$, substantia nigra, pars compacta; $S N p r$, substantia nigra, pars reticulata. Scale bars: $A$ and $B, 0.5 \mathrm{~mm} ; A^{\prime}$ and $B^{\prime}, 50 \mu \mathrm{m}$.

granule cells die, having failed to (1) extend bipolar processes, (2) form specific associations with adjacent Bergman glial guides, and (3) complete successful migration from the external to the internal granule cell layer. The most compelling evidence point-

\section{Table 4. Content of dopamine in 3 forebrain regions containing intrinsic neurons that synthesize dopamine: retina, hypothalamus, and olfactory bulb}

\begin{tabular}{lcl} 
& \multicolumn{2}{c}{ Dopamine (pmol/mg protein) } \\
\cline { 2 - 3 } Region & $+/ \mathrm{wv}$ & wv/wv \\
\hline Retina & $8.9 \pm 0.5$ & $8.3 \pm 0.5$ \\
& & $(93 \%)$ \\
Olfactory bulb & $12.2 \pm 0.1$ & $11.7 \pm 1.3$ \\
& & $(96 \%)$ \\
Hypothalamus & $66.9 \pm 7.4$ & $45.9 \pm 5.4^{a}$ \\
& & $(68 \%)$
\end{tabular}

Values represent means \pm SEM of 5-10 samples. Weaver animals were compared with heterozygous littermates. Olfactory bulbs were examined in animals 48-74 $\mathrm{d}$ of age, retinas were from animals $65-142 \mathrm{~d}$ old, and hypothalami were from animals $73-188 \mathrm{~d}$ old. Numbers in parentheses are percent of heterozygous control littermate values.

${ }^{a} p<0.05$. ing to the granule cell as a direct target of the weaver gene has come from the study of chimeras formed by fusion of normal $(+/+)$ and heterozygous weaver (+/wv) embryos (Goldowitz and Mullen, 1982). In chimeric cerebella that contained a mixture of heterozygote weaver cells and wild-type cells, the only granule cells found in ectopic positions were those bearing a weaver gene. These cells failed to migrate to the appropriate destination in spite of the presence of normal Bergman glia. Experiments on cultured weaver cerebellar cells support the hypothesis that the weaver defect is intrinsic to the granule cell (Hatten et al., 1984a, b; Willinger and Margolis, 1984a, b), though they also demonstrate an interdependence of young granule cells and Bergman glial cells (see below). None of these studies, including those of the chimeric mice, has eliminated the Bergman glia as being an additional primary target of the weaver gene.

The cerebellum and the mesencephalic dopamine-containing neurons are not linked by direct pathways, so that the abnormalities in the weaver's dopamine-containing systems are certainly not easily attributable to secondary effects of the cerebellar pathology. The findings presented here strongly suggest that the weaver mutation affects a subset of dopamine-containing neurons in the midbrain and that these neurons either comprise a primary site of action of the weaver gene or are intimately 
Table 5. Content of norepinephrine in the targets of the mesotelencephalic dopamine-containing systems and the midbrain, the olfactory bulb, and the hypothalamus

\begin{tabular}{llcc} 
& \multicolumn{3}{c}{ Norepinephrine (pmol/mg protein) } \\
\cline { 2 - 4 } Region & $1 / 1$ & $+/$ wv & wv/wv \\
\hline Caudoputamen & $7.7 \pm 0.6$ & $7.3 \pm 3$ & $7.4 \pm 0.8$ \\
Olfactory tubercle & $16 \pm 1$ & $12 \pm 1$ & $13 \pm 1$ \\
Nucleus accumbens & $31 \pm 3$ & $30 \pm 1$ & $29 \pm 2$ \\
Septum & $38+3$ & $44+4$ & $48+4$ \\
Amygdala & - & $43 \pm 4$ & $57 \pm 9$ \\
Frontal cortex & - & $25 \pm 1$ & $28 \pm 2$ \\
Midbrain & $36 \pm 4$ & $41 \pm 2$ & $41 \pm 4$ \\
Olfactory bulb & - & $19 \pm 2$ & $17 \pm 2$ \\
Hypothalamus & - & $215 \pm 5$ & $266 \pm 15$
\end{tabular}

Values are mean \pm SEM of 3-17 samples. The animals used ranged in age from 1 to 6 months.

connected with such a site. The deficit in dopamine found in the weavers was remarkable for its clean and stable boundaries, reproduced in detail in each animal but appearing only in the weaver mutants among the group of 3 ataxic mutants studied. The fact that neither the staggerer nor the Purkinje cell degeneration mouse mutations showed alterations in striatal dopamine eliminates ataxic movement and cerebellar neuropathology as direct causes of the dopamine depletion in the weaver striatum, and also shows that mutations affecting the cerebellum do not necessarily also affect the striatum.

The best evidence that the reduction of dopamine in weaver is related to a primary site of the action of the weaver gene was the finding of a dose-dependent effect of the gene. In both the caudoputamen and the olfactory tubercle, the 2 striatal regions in which we have found dopamine to be deficient in the homozygous weaver animals, a less marked but significant defect in dopamine was present in the nonataxic heterozygous weaver mice. Gene dose-dependence has already been demonstrated for action of the weaver gene in the cerebellum. A slowed rate of migration of granule cells occurs in the heterozygous weaver cerebellum (Rezai and Yoon, 1972), and the heterozygote suffers a modest loss of granule cells and some disorganization of laminar structure (Rakic and Sidman, 1973a-c). Cultured heterozygous granule cells show abnormal neurite growth (Willinger and Margolis, 1985a, b) and reduced viability (Hatten et al., 1984a; Willinger and Margolis, 1985a, b). The shape, wet weight, content of protein and neurotransmitter-related compounds of the heterozygous weaver cerebellum (Rakic and Sidman, 1973ac; Roffler-Tarlov and Turey, 1982), and the tyrosine hydroxylase activity of the locus coeruleus (Black, 1976b) are also distinguishable from those of both the homozygous normal and the homozygous weaver cerebellum. Our finding of similar dosedependent effects on dopamine-containing systems in weaver suggests that the primary actions of the weaver gene are exerted on at least 2 widely separated sites in the weaver brain, viz., the cerebellum and the substantia nigra. It is of interest that concomitant degenerative changes in these 2 structures occur in hereditary diseases in the human; for example, familial olivopontocerebellar degeneration (Jellinger, 1968) and striatonigral degeneration (Rosenberg et al., 1978).

\section{Range of action of the weaver mutation in the forebrain and} midbrain

The survey of regions affected and spared in the weaver brains gave clues to the dopamine-containing subsystems vulnerable to the effects of the mutation. First, there was clear evidence for a loss of dopamine in the midbrain. The magnitude of the defect,
Table 6. Content of dopamine in 3 striatal regions of 2 ataxic mutant mice: staggerer and Purkinje cell degeneration (pcd)

\begin{tabular}{lllll} 
& \multicolumn{4}{l}{ Dopamine (pmol/mg protein) } \\
\cline { 2 - 5 } Region & Control & Staggerer & Control & pcd \\
\hline Caudoputamen & $466 \pm 17$ & $460 \pm 16$ & $403 \pm 12$ & $405 \pm 18$ \\
Olfactory tubercle & $247 \pm 14$ & $217 \pm 25$ & $304 \pm 19$ & $316 \pm 17$ \\
Nucleus accumbens & $341 \pm 14$ & $366 \pm 9$ & $335 \pm 18$ & $316 \pm 20$
\end{tabular}

Values represent means \pm SEM of 4-8 samples. Staggerer and control animals ranged in age between 1 and 14 months. Control animals for the staggerer mutants were littermates or aged matched animals that were $+/+$ at the sg locus. Controls for the pcd/pcd animals were littermates that could have been $+/+$ or $+/$ pcd animals. These mice were 6 months old.

amounting to about $30 \%$ relative to heterozygous controls and homozygous normals, was similar to that measured in our original study of dopaminc in the wcaver brain (Roffler-Tarlov and Graybiel, 1984). Schmidt et al. (1982) did not observe decreased levels of dopamine in whole brain stem samples from weavers, and Black (1976a) found normal activity of tyrosine hydroxylase in samples of substantia nigra from weaver mice. Schmidt et al. (1982) did report a loss of neurons in the substantia nigra pars compacta of the mutants. Such a loss is consonant with our biochemical findings. Preliminary immunohistochemical experiments suggest a partial reduction of tyrosine hydroxylasepositive neurons in the pars compacta of the weaver's substantia nigra in sections reacted with antibodies to this enzyme (A. M. Graybiel and S. Roffler-Tarlov, unpublished observations). It remains to be determined whether this deficit reflects a loss of neurons or whether neurons are present but elude detection because they do not express tyrosine hydroxylase in appreciable amounts. It is not yet clear whether there is a loss of tyrosine hydroxylase-positive neurons elsewhere in the dopamine-containing cell groups of the midbrain. Strain differences in the numbers of mesencephalic neurons expressing tyrosine hydroxylase have been observed in quantitative studies of such neurons in inbred mice (Baker et al., 1980). The numbers of tyrosine hydroxylase-positive neurons in restricted parts of the substantia nigra, pars compacta, and ventral tegmental area of the BALB/ cJ and CBA/J strains differ by about $20 \%$.

For the striatum, our findings confirmed a selective sparing of dopamine in the nucleus accumbens, which receives its dopamine-containing input from the ventral tegmental area and the adjoining medial part of the pars compacta of the substantia nigra. The concentration of dopamine in the olfactory tubercle, already demonstrated to be deficient in the weaver mice compared to heterozygote controls, was shown to be even more significantly affected when the homozygous mutants were compared to homozygous normal mice on the same background. These measurements received support from the anatomical findings. The presence of intense fluorescence in the nucleus accumbens and in medial regions of olfactory tubercle of the weaver mutants cannot be attributed to an increased content of norepinephrine because the content of this transmitter was unchanged in both structures.

The clear-cut differences in vulnerability between dopamine in the nucleus accumbens and in the olfactory tubercle favor the view that these structures should continue to be considered as distinct elements of the basal forebrain despite the fact that they both receive a mesolimbic dopamine innervation and that they are included together as the main components of the ventral striatum (Heimer and Wilson, 1975). The histofluorescence sections further suggest a differential vulnerability of the lateral part of the olfactory tubercle in the weaver animal. This pattern may reflect greater innervation of the medial than the lateral part by particular neurons of the ventral tegmental area and 
dorsomedial part of the adjoining pars compacta of the substantia nigra. In the rat at least, cholecystokinin-immunoreactive fibers are especially concentrated in the medial part of the olfactory tubcrclc (Fallon et al., 1983; Hökfelt et al., 1980a, b), and these fibers are thought to originate in the ventral tegmentalnigral complex (Hökfelt et al., 1980a, b; Skirboll et al., 1981). The medial part of the olfactory tubercle is also thought to receive mainly the "dotted" type of dopamine-containing afferents, rather than the "diffuse" type-so named by Fuxe et al. (1983) for their appearance in sections prepared for formaldehyde-induced fluorescence (Fuxe et al., 1979, 1983). Given the present finding that some fluorescence persists in the medial part of the olfactory tubercle in the heterozygous and homozygous weavers, one possibility is that the weaver mutation particularly affects the diffuse as opposed to the dotted (possibly cholecystokinin-containing) type of dopamine-containing afferents innervating the olfactory tubercle. Alternatively, the dotted type may have a higher terminal dopamine content, so that comparable deficits produce apparent selective sparing.

Of other regions receiving a mesotelencephalic dopaminecontaining innervation, only the septum was found to have reduced dopamine in the weaver mutants. The septal region receives dopamine-containing afferents from 2 sources. A mesencephalic innervation arises from a localized paramedian region at the border between the pars compacta of the substantia nigra and the ventral tegmental area (Fallon, 1981; Fallon and Moore, 1978). A similar region is reported to innervate the medial caudoputamen, which was also severely affected in the weaver mice. According to Fallon (1981), the ventral tegmental neurons innervating the septum do not provide a strong collateral innervation of the medial caudoputamen, but some medially situated pars compacta neurons do send collaterals to both regions (and to prefrontal cortex). The second dopamine-containing innervation of the septum arises from cells of the incertohypothalamic dopamine system (Bjorklund and Lindvall, 1978). We could not distinguish between these mesencephalic and diencephalic cell groups as being responsible for the deficit in septal dopamine in the weaver mice. Indeed, the levels in the septum, hypothalamus-preoptic area, and midbrain were all reduced by the same amount (ca. $30 \%$ ) relative to heterozygote controls.

The 30\% deficit in dopamine in the hypothalamus of the weaver was the only finding suggesting that the weaver mutation may have affected dopamine-containing cell bodies other than those of the midbrain cell groups A8-A10. The normal concentration of dopamine was present in the retina and the olfactory bulb, the 2 other regions with dopamine-containing neurons analyzed. The decrease measured in the hypothalamus is difficult to interpret, however, because as much as $40 \%$ of the dopamine in the hypothalamus is thought to originate in the midbrain, in the ventral tegmental area (see Kizer et al., 1976). Furthermore, the hypothalamic dopamine-containing neurons are not easily dissected away from those in the zona incerta (cell group A13) or from the rostral pole of the mesencephalic dopamine-containing cell complex. We made an effort to exclude cell group 13 from the hypothalamic samples but were uncertain whether the caudal hypothalamic cell group All was included in the hypothalamic or in the midbrain samples (or in both).

The findings for the frontal cortex merit special comment. Our biochemical measurements failed to demonstrate a loss of dopamine in the frontal cortex of the weaver mutants. Schmidt et al. (1982) did find a reduction of dopamine in their samples of frontal cortex and, in fact, reported as large a deficit in this target of the mesocortical system (70\%) as in the caudoputamen. We have no ready explanation for the difference between these findings and our own. Details of the protocols for dissection, however, could have critically affected the values obtained. In our own dissections, we removed frontal cortex only from the
4 slices anterior to the rostral pole of the caudoputamen because our first priority was to avoid involvement of the striatum in the frontal cortex samples. We therefore did not sample all of the rostral cortex inncrvated by the mesocortical systcm. For example, little of the anterior cingulate area was included (Bjorkland and Lindvall, 1978; Fallon, 1981). In the pregenual frontal tissue analyzed, however, the findings were unequivocal in suggesting sparing of the mesocortical projection.

Taken together, our findings suggest a remarkable specificity in the dopamine-containing systems affected by the weaver mutation. Of regions innervated by mesencephalic cell groups A8A10, the nucleus accumbens, amygdala, and prefrontal cortex appear to be spared; but the caudoputamen, olfactory tubercle, septum, and hypothalamus appear to be affected. No single known functional or anatomical category adequately embraces all of the members of either group of structures. On the other hand, certain functional and anatomical dividing lines-for example, between the caudoputamen and the nucleus accumbens-were closely reflected in the pattern of genetic loss. An important generalization suggested by the present findings is that a genetic defect can affect highly restricted parts of the dopamine-containing innervation of the forebrain. By extension, it seems plausible that in other heritable diseases, dopamine concentrations in the frontal cortex, in the nucleus accumbens, or in the amygdala might be affected. Notable in this context is evidence for abnormalities in the dopamine content of the frontal cortex and the amygdala in postmortem brain samples from patients diagnosed as schizophrenics (Bird et al., 1979; Reynolds, 1983).

Our findings are incomplete in that we did not sample all regions receiving a dopamine-containing innervation. For example, we did not include the bed nucleus of the stria terminalis, nor the anterior olfactory area, piriform cortex and entorhinal area, nor the zona incerta. The fact that dopamine was affected in a range of the structures sampled in the weaver brain, not only in the caudoputamen and in the midbrain, tends to point to the dopamine-containing neurons in the brain stem, as opposed to their postsynaptic receptor sites in the forebrain, as being first affected in the progression of the weaver disease.

\section{Biochemical specificity of the genetic defect}

The weaver's defect was specific for dopamine among catecholamines. This conclusion was drawn by Schmidt et al. (1982) and was confirmed in the present study for all regions examined, regardless of whether the regions had high or low concentrations of norepinephrine and whether the region was affected or spared in terms of its dopamine content. The fact that norepinephrine content is unaltered by the mutation also indicates that the pool of dopamine available as a precursor in the synthetic pathway for norepinephrine is unaffected.

Comparisons of the concentrations of dopamine and its metabolite DOPAC showed no convincing increase in the content of the metabolite relative to that of dopamine in any striatal region of weaver homozygotes or heterozygotes. This result stands in marked contrast to that obtained after subtotal neurotoxininduced destruction of thc dopamine innervation of the striatum. After the administration of 6-hydroxydopamine, striatal dopamine is permanently decreased and the content of DOPAC is increased relative to the content of dopamine (Zigmond et al., 1984). This result is interpreted as indicating a compensatory increased synthetic activity on the part of surviving dopaminccontaining neurons. No such compensatory mechanisms were evident in the weaver's striatum. The dissimilarity may point to a fundamental difference in the response of residual dopamine-containing neurons following an aggressive insult produced by neurotoxins and following a more slowly evolving (and in weaver, genetically determined) process. 


\section{The dopamine defect in weaver: parallels with the cerebellar} defect

The weaver disease is a consequence of the action of a single gene. Thus, the genetic events that result in the pathologies expressed in the dopamine-containing regions of the brain and in the cerebellum must be caused by a common molecular mechanism. Although the immediate cellular events underlying these pathologies could be quite different, knowledge of the mutation as it is expressed in the cerebellum may nevertheless inform work focused on the dopamine-containing systems. Three key characteristics of the defect in the weaver cerebellum are noted here:

1. The disease as expressed in the cerebellum is a developmental disorder with a visible onset in the early postnatal period. It produces a gene dose-dependent impairment as discussed above, and regional variations in degree of expression occur in different parts of the cerebellum (Herrup and Trenkner, 1985). Similarly, the full deficit in dopamine is present by the end of the first month of life, does not increase with advancing age, shows sharp regional specificity, and reflects a failure of normal maturational increases in the dopamine content of the affected striatal regions (Roffler-Tarlov and Graybiel, 1985a; Schmidt et al., 1982).

2 . The weaver gene mutation has a primary neuronal target in the cerebellum - the granule cell. For the dopamine system, it seems likely that a subset of neurons in the midbrain (and possibly in the hypothalamus) are the primary neuronal targets. Similarities between the dopamine-containing neurons and cerebellar granule cells are not obvious, however. They have different perikaryal, dendritic, and axonal morphologies; they express different neurotransmitters; and they arise from different parts of the germinal epithelium during embryogenesis (see Marchand and Poirier, 1983). The critical commonality is likely to be subtle.

3. The death of the cerebellar granule cells in weaver mutants is thought to result from their failure to migrate from the site of their birth in the external granular layer to the internal granular layer (Rezai and Yoon, 1972). Interactions between the granule cells and Bergman glial guide fibers have been implicated in this pathological process. Rakic and Sidman (1973ac) concluded that the failure of granule cell migration was secondary to defects in the Bergman glia, which in weaver mice are stunted, reduced in number, and unevenly spaced (Bignami and Dahl, 1974). An effect of the mutant gene on these glial cells has neither been proven nor thoroughly discounted, but subsequent work has shown that the fate of the granule cells is not fully dependent on the Bergman glia: Some granule cells die after successful migration to the internal granule cell layer (Sotelo and Changeux, 1974). The nature of the interaction between granule cells and Bergman glial has been probed using young cultured cerebellar cells. The weaver granule cell does not make a close contact with the Bergman glial guide fibers even when cocultured with genetically normal Bergman glial cells (Hatten et al., 1984a, b). Thus, cell-cell interactions apparently necessary for migration of the granule cells are aberrant in the weaver cerebellum.

Given this evidence, it is appealing to think that the defect in the dopamine-containing fiber systems in the weaver brain may also result from abnormal patterns of interaction among neurons destined to synthesize dopamine and other cells, perhaps glial cells. A common molecular mechanism would thus be expressed also in common phenomenological features during the progression of the pathologies. However, the timing of events could not be similar for the cerebellar and dopamine systems if a migratory defect is at issue. The postnatal time of migration of cerebellar granule cells is exceptional. There is no evidence that neurons of the nigral complex undergo major waves of migration postnatally. According to Marchand and Poirier (1983), they migrate in medial and lateral groups during embryonic days E15-18. However, other postnatal defects in cellcell interactions could lead to the dopamine defect in the weaver brain. For example, neurite extension and guidance both require such interactions (Edelman, 1984). Especially pertinent here are the findings of Denis-Donini et al. (1984) and Hemmendinger et al. (1981), who have found that extrinsic signals influence the outgrowth of neurites by mesencephalic neurons cultured from normal mice. Abnormal growth signals or abnormal responses to such signals might result in defects in neurite formation in the weaver midbrain, with or without subsequent death of the neurons. Just such defects have been found in weaver cerebellar granule cells grown in culture. Relative to normal granule cells, the mutant neurons show an increased frequency of neurite retraction, a markedly slowed rate of growth cone elongation, and shortened neurite length (Willinger and Margolis, 1985a, b).

\section{References}

Baker, H., T. H. Joh, and D. J. Reis (1980) Genetic control of number of midbrain dopaminergic neurons in inbred strains of mice: Relationship to size and neuronal density of the striatum. Proc. Natl. Acad. Sci. USA 77: 4369-4373.

Bignami, A., and D. Dahl (1974) The development of Bergmann glia in mutant mice with cerebellar malformations: Reeler, staggerer and weaver. Immunofluorescence study with antibodies to the glial fibrillary acidic protein. J. Comp. Neurol. 155: 219-230.

Bird, E. D., E. G. S. Spokes, and L. L. Iversen (1979) Increased dopamine concentration in limbic areas of brain from patients dying with schizophrenia. Brain 102: 347-360.

Björklund, A., and O. Lindvall (1978) The mesotelencephalic dopamine neuron system: A review of its anatomy. In Limbic Mechanisms, K. E. Livingston and O. Hornykiewicz, eds., pp. 307-331, Plenum, New York.

Black, I. B. (1976a) Abnormal brain catecholamine enzymes in weaver mutant mice. Brain Res. 105: 602-605.

Black, I. B. (1976b) Apparent intermediate expression of elevated tyrosine hydroxylase activity in brain of weaver mutant mice. Brain Res. 110: 635-637.

Caddy, K. W. T., and T. J. Biscoc (1979) Structural and quantitative studies on the normal $\mathrm{C} \mathrm{H}$ and Lurcher mutant mouse. Philos. Trans. R. Soc. Lond. [Biol.] 287: 167-201.

Dahlstrom, A., and K. Fuxe (1964) Evidence for the existence of monoamine containing neurons in the central nervous system. I. Demonstration of monoamines in the cell bodies of brain stem neurons. Acta Physiol. Scand. [Suppl. 232] 62: 1-55.

Denis-Donini, S., J. Glowinski, and A. Prochiantz (1984) Glial heterogeneity may define the three-dimensional shape of mouse mesencephalic dopaminergic neurons. Nature 307:641-643.

Edelman, G. M. (1984) Modulation of cell adhesion during induction, histogenesis, and perinatal development of the nervous system. Annu. Rev. Neurosci. 7: 339-377.

Fallon, J. H. (1981) Collateralization of monoamine neurons: Mesotelencephalic dopamine projections to caudate, septum, and frontal cortex. J. Neurosci. 1: 1361-1368.

Fallon, J. H., and R. Y. Moore (1978) Catecholamine innervation of the basal forebrain. IV. Topography of the dopamine projection to the basal forebrain and neostriatum. J. Comp. Neurol. 180:545-580.

Fallon, J. H., R. Hicks, and S. E. Loughlin (1983) The origin of cholecystokinin terminals in the basal forebrain of the rat: Evidence from immunofluorescence and retrograde tracing. Neurosci. Lett. 37: 2935 .

Fuxe, K., K. Andersson, R. Schwarcz, L. F. Agnati, M. Perez de la Mora, T. Hökfelt, M. Goldstein, L. Ferland, L. Possani, and R. Tapia (1979) Studies on different types of dopamine nerve terminals in the forebrain and their possible interaction with hormones and with neurons containing GABA, glutamate and opioid peptides. Adv. Neurol. 24: 199-215.

Fuxe, K., L. F. Agnati, S.-O. Ogren, C. Kohler, L. Calza, F. Benfenati, M. Goldstein, K. Andersson, and P. Eneroth (1983) The heterogeneity of the dopamine systems in relation to the actions of dopamine agonists. Acta Pharm. Suec. [Suppl.] 60-79. 
Goldowitz, D., and R. J. Mullen (1982) Granule cell as a site of gene action in the weaver mouse cerebellum: Evidence from heterozygous mutant chimeras. J. Neurosci. 2: 1474-1485.

Hatten, M. E., R. K. H. Liem, and C. A. Mason (1984a) Defects in specific associations between astroglia and neurons occur in microcultures of weaver mouse cerebellar cells. J. Neurosci. 4: 1163-1172.

Hatten, M. E., R. K. H. Liem, and C. A. Mason (1984b) In vitro recombination of neurons and astroglia purified from normal and weaver mouse cerebellum. Soc. Neurosci. Abstr. 50.8 .

Heimer, L., and R. D. Wilson (1975) The subcortical projections of the allocortex: Similarities in the neural associations of the hippocampus, the piriform cortex, and the neocortex. In Golgi Centennial Symposium, Proceedings, M. Santini, ed., pp. 177-193, Raven, New York.

Hemmendinger, L. M., B. B. Garber, P. C. Hoffmann, and A. Heller (1981) Target neuron-specific process formation by embryonic mesencephalic dopamine neurons in vitro. Proc. Natl. Acad. Sci. USA 78: 1264-1268.

Herrup, K., and R. J. Mullen (1979) Regional variation and absence of large neurons in the cerebellum of the staggerer mouse. Brain Res. 172: $1-12$.

Herrup, K., and E. Trenkner (1985) The weaver mutation: Regional variations in cerebellar development and proposed early time of gene action. Soc. Neurosci. Abstr. 292.8.

Hökfelt, T., J. F. Rehfeld, L. Skirboll, B. Ivemark, M. Goldstein, and K. Markey (1980a) Evidence for coexistence of dopamine and CCK in meso-limbic neurons. Nature 285: 476-478.

Hökfelt, T., L. Skirboll, M. F. Rehfeld, M. Goldstein, K. Markey, and O. Dann (1980b) A subpopulation of mesencephalic dopamine neurons projecting to limbic areas contains a cholecystokinin-like peptide: Evidence from immunohistochemistry combined with retrograde tracing. Neuroscience 5: 2093-2124.

Jellinger, K. (1968) Degenerations and exogenous lesions of the pallidum and striatum. In Handbook of Clinical Neurology, Vol. 6, P. J. Vinten and G. W. Bruyn, eds., North-Holland, Amsterdam.

Kizer, J. S., M. Palkovits, and M. J. Brownstein (1976) The projections of the A8, A9 and A10 dopaminergic cell bodies: Evidence for a nigral-hypothalamic-median eminence dopaminergic pathway. Brain Res. 108: 363-370.

Landis, D. M. D., and R. L. Sidman (1978) Electron microscopic analysis of postnatal histogenesis in the cerebellar cortex of staggerer mutant mice. J. Comp. Neurol. 179: 831-863.

Lane, J. D., N. S. Nadi, W. J. McBride, M. H. Aprison, and K. Kusano (1977) Contents of serotonin, norepinephrine and dopamine in the cerebrum of the "staggerer," "weaver" and "nervous" neurologically mutant mice. J. Neurochem. 29: 349-350.

Lowry, O. H., N. J. Rosebrough, A. L. Farr, and R. J. Randall (1951) Protein measurement with the Folin phenol reagent. J. Biol. Chem. 193: 265-275.

Marchand, R., and L. J. Poirier (1983) Isthmic origin of neurons of the rat substantia nigra. Neuroscience 9: 373-381.

Moyer, T. P., and N.-S. Jiang (1978) Optimized isocratic conditions for analysis of catecholamines by high performance reversed-phase paired-ion chromatography with amperometric detection. J. Chromatogr. 153: 365-373

Mullen, R. J., E. M. Eicher, and R. L. Sidman (1976) Purkinje cell degeneration, a new neurological mutation in the mouse. Proc. Natl. Acad. Sci. USA 73: 208-212.

Nauta, W. J. H., G. P. Smith, R. L. M. Faull, and V. B. Domesick (1978) Efferent connections and nigral afferents of the nucleus accumbens septi in the rat. Neuroscience 3: 385-401.

Rakic, P., and R. L. Sidman (1973a) Weaver mutant mouse cerebellum: Defective neuronal migration secondary to abnormality of Bergmann glia. Proc. Natl. Acad. Sci. USA 70: 240-244.

Rakic, P., and R. L. Sidman (1973b) Sequence of developmental abnormalitics leading to granule cell deficit in cercbcllar cortex of wcaver mutant mice. J. Comp. Neurol. 152: 103-132.

Rakic, P., and R. L. Sidman (1973c) Organization of cerebellar cortex secondary to deficit of granule cells in weaver mutant mice. J. Comp. Neurol. 152: 133-162.

Reynolds, G. P. (1983) Increased concentrations and lateral asymmetry of amygdala dopamine in schizophrenia. Nature 305:527-529.
Rezai, Z., and C. H. Yoon (1972) Abnormal rate of granule cell migration in the cerebellum of "weaver" mutant mice. Dev. Biol. 29: $17-26$.

Roffler-Tarlov, S., and A. M. Graybiel (1984) Weaver mutation has differential effects on the dopamine-containing innervation of the limbic and nonlimbic striatum. Nature 307: 62-66.

Roffler-Tarlov, S., and A. M. Graybiel (1985a) Dopamine abnormality in weaver mouse: Development and heterozygote effect. Am. Soc. Neurochem. Abstr. 110.14.

Romler-Tarlov, S., and A. M. Graybiel (1985b) Dose-dependent expression of the weaver gene on the dopamine-containing innervation of the forebrain and effects outside of the striatum. Soc. Neurosci. Abstr. 110.14.

Roffler-Tarlov, S., and M. Turey (1982) The content of amino acids in the developing cerebellar cortex and deep cerebellar nuclei of granule cell deficient mutant mice. Brain Res. 247: 65-73.

Rosenberg, R. N., W. L. Nyhan, P. Coutinho, and C. Bay (1978) Joseph disease: An autosomal dominant neurological disease in the Portuguese of the United States and the Azores Islands. In The Inherited Ataxias, P. Kark, R. Rosenberg, and L. Schert, eds., pp. 33-57, Raven, New York

Schmidt, M. J., B. D. Sawyer, K. W. Perry, R. W. Fuller, M. M. Foreman, and B. Ghetti (1982) Dopamine deficiency in the weaver mutant mouse. J. Neurosci. 2: 376-380.

Sidman, R. L. (1968) Development of interneuronal connections in the brain of mutant mice. In Physiological and Biochemical Aspects of Nervous Integration, F. D. Carlson, ed., pp. 163-193, PrenticeHall, Englewood Cliffs, NJ.

Sidman, R. L., P. W. Lane, and M. M. Dickie (1962) Staggerer, a new mutation in the mouse affecting the cerebellum. Science 137:610612

Sidman, R. L., M. C. Green, and S. H. Appel (1965) Catalog of the Neurological Mutants of the Mouse, pp. 66-67, Harvard University Press, Cambridge, MA.

Skirboll, L. R., A. A. Grace, D. W. Hommer, J. Reafeld, M. Goldstein, T. Hökfelt, and B. S. Bunney (1981) Peptide-monoamine coexistence: Studies of the actions of cholecystokinin-like peptide on the electrical activity of midbrain dopamine neurons. Neuroscience 6 : 2111-2124.

Sotelo, C. (1975) Dendritic abnormalities of Purkinje cells in the cerebellum of neurologic mutant mice (weaver and staggerer). Adv. Neurol. 12: $335-351$.

Sotelo, C., and J. P. Changeux (1974) Bergmann fibers and granular cell migration in the cerebellum of homozygous weaver mutant mouse. Brain Res. 77: 484-491.

de la Torre, J. C. (1980) An improved approach to histofluorescence using the SPG method for tissue monoamines. J. Neurosci. Methods 3: $1-5$.

Ungerstedt, U. (1971) Stereotaxic mapping of the monoamine pathways in the rat brain. Acta Physiol. Scand. [Suppl. 367] 82: 1-48.

Wetts, R., and Herrup, K. (1982) Interaction of granule, Purkinje and olivary neurons in Lurcher chimeric mice. I. Qualitative studies. J. Embryol. Morphol. 68: 87-98.

Willinger, M., and D. M. Margolis (1985a) Effect of the weaver (wv) mutation on cerebellar neuron differentiation. I. Qualitative observations of neuron behavior in culture. Dev. Biol. 107: 156-172.

Willinger, M., and D. M. Margolis (1985b) Effect of the weaver (wv) mutation on cerebellar neuron differentiation. I. Qualitative obserron behavior in culture. Dev. Biol. 107: 173-179.

Winer, B. J. (1971) Statistical Principles in Experimental Design. 2nd ed., pp. 215-219, McGraw-Hill, New York

Zigmond, M. J., A. L. Acheson, M. K. Stachowiak, and E. M. Strickerm (1984) Neurochemical compensation after nigrostriatal bundle injury in an animal model of preclinical parkinsonism. Arch. Neurol. 41: $856-861$.

Zigmond, R. E., and Y. Ben-Ari (1976) A simple method for the serial sectioning of fresh brain and the removal of identifiable nuclei from stained sections for biochemical analysis. J. Neurochem. 26: 12851287. 